\title{
Ryckaert at work: A Flemish painter's view of labour $^{1}$
}

Bernadette van Haute*

\author{
*Bernadette van Haute is Senior Lecturer in \\ the Department of Art History, Visual Arts and \\ Musicology at the University of South Africa.
}

\begin{abstract}
In his depictions of men at work, David III Ryckaert reveals an acute awareness of social differentiation on the basis of professional identity. The craftsman is invariably depicted as an example of industry and diligence, a view strengthened by the inclusion of the artisan's spinning wife. Ryckaert, however, made sure to remind the viewer of the fundamental baseness of the labouring classes, whereas professions of a more intellectual nature (such as artists) were treated with greater respect. This reflects the artist's desire, shared by his clients, to consolidate and justify the social order. By using his art 'tot leeringh vande jeught' (to instruct the youth), he actively contributed to the shaping of social norms.
\end{abstract}

\section{Introduction}

David III Ryckaert (2 December 1612 - 11 November 1661) produced a relatively large number of paintings representing men at work. The trades and professions he chose to portray include those of the alchemist, barber-surgeon, blacksmith, butcher, carpenter, cobbler, painter and vendor. It was, however, the theme of the cobbler in his workshop that became one of his specialities and which he practised over a long period of time. Ryckaert chose to treat his depictions of men at work - both manual labour and work of a more intellectual nature - as peasant paintings. In this article, I aim to show that the artist set out to differentiate between the social classes to which these professionals belonged. Ryckaert would depict the craftsman in his workshop (more particularly the cobbler and the blacksmith) as an industrious labourer, but add a satirical element to stress and even mock his lower social status. The artist in his studio and the alchemist in his laboratory, on the other hand, were not subjected to the derisive commentary usually associated with the peasant genre. During the 1640s Ryckaert's approach to the theme of the cobbler's workshop shifted towards a more genteel treatment, aided by the inclusion of the artisan's wife. The motif of the supportive wife also made its appearance in his depictions of the alchemist in his laboratory. The artist's choices will be explained with reference to the available literature and art, and the reputation of the peasant genre. I will also investigate the influence of contextual forces such as changes in the social climate, market conditions and the general expectations of the artist's clients in an attempt to reconstruct his view of labour.

\section{Ryckaert's early representations of labour}

Ryckaert was first and foremost a painter of peasant scenes. ${ }^{2}$ Peasant painting enjoyed considerable popularity in Flanders from the 1630s onwards (Renger in Sutton 19931994:73). ${ }^{3}$ The genre of peasant painting had its origin in the fifteenth-century literary tradition of peasant satire; the pictorial tradition itself came to fruition in the sixteenth century, especially with Pieter Brueghel the Elder. ${ }^{4}$ Adriaen Brouwer was instrumental in the revival of the theme in seventeenth-century Antwerp, where the appreciation of the public for peasant scenes led David Ryckaert to follow his example. From the start of his artistic career Ryckaert displayed a particular liking for this branch of genre painting (Van Haute 1999:20). Iconographic research has revealed that peasant pictures are not realistic in the sense that they are contrived compositions designed to convey a particular meaning, and are thus devoid of documentary value (Vandenbroeck 1990:42). Within this genre, as a rule the peasants are shown to display the kind of excessive and coarse behaviour that one should avoid. ${ }^{5}$ They are the perfect vehicle through which to display all kinds of vices. As far as the social function of the peasant genre is concerned, it is commonly agreed that these images served to satirise the lower classes and rustics (de lompe boer or the rural misfit) for the amusement and edification of a self-conscious urban elite (Vandenbroeck 1984:119). The public liked this kind of painting, not so much for its presumed moralising and didactic undertones as for its risibility, that is, its capacity to elicit laughter (Vekeman and Müller Hofstede 1984:139).

Ryckaert painted his first representation of a man at work, namely The Cobbler (1), in 1638 , shortly after his registration as a master of the Guild of St Luke in Antwerp in 1636-37. In this painting the main actors are the cobbler, who is portrayed as a bearded young man wearing a feathered cap, and a young woman 


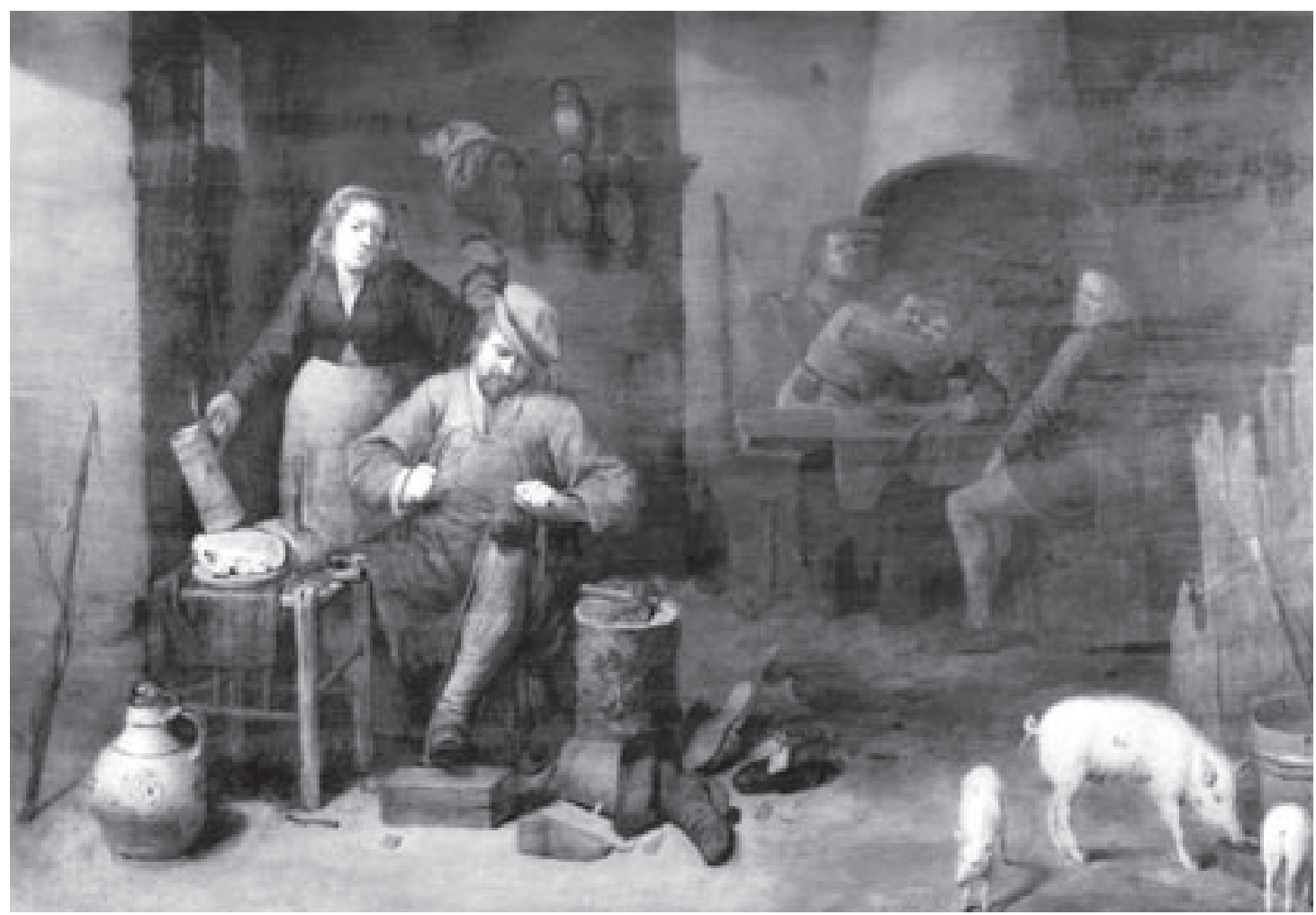

1 David III Ryckaert, The Cobbler. Oil on panel, $57 \times 81 \mathrm{~cm}$. Signed and dated on piece of paper middle right: D.Ryc.f 1638. Location unknown (Van Haute 1999, Cat. A14).

standing behind him with a beer-tankard in her right hand. Wearing a leather apron, the young cobbler earnestly concentrates on the task of fashioning a shoe. Using a leather band tied around his foot and knee, the shoe remains fixed to his left thigh. With the help of a footrest the leg is slightly raised, which allows him to work freely with both hands, sewing the leather upper part of the shoe to the sole. The cobbler's tools lie within his reach on a tree trunk to his left, while different types of footwear, pieces of leather and a shoe-last litter the floor. ${ }^{6}$ The sparse interior can further be identified as the cobbler's workshop owing to the depiction of a shelf against the back wall, from which hang three newly fashioned shoes. This part of the imagery in The Cobbler seems based on reality. When one compares it to other representations of cobblers, ${ }^{7}$ the similarities point to a certain degree of realism and documentary value. As for the remainder of the scene portrayed, there is nothing here to suggest a serious working environment. In the background the artist has included a group of four drinking peasants, gathered around a table in front of a fireplace. One of the men is seen embracing a woman and sneaking his hand into her décolletage, creating an atmosphere of uninhibited lustfulness.

This scene is not simply a concoction of the artist's imagination guided by Christianhumanist values: it is also informed by literary and pictorial tradition. In sixteenth- and seventeenth-century Netherlandish literature and art, a cobbler's workshop was a popular setting for the enactment of the vices of sloth and drunkenness. The Flemish folk figures 'Sorgheloos' and 'Verlega' were used as 'models of negligent behaviour nominally in charge of a shoemaker's house and shop' (Liedtke 1984:238-240). A visual depiction of this tradition is the copperplate engraving by Pieter Baltens of Sorgheloos en Verlega (2). As a personification of sloth, 'Sorgheloos', the man on the right, has set aside his work to play the bagpipe (Moens 1994:132). On the left is his wife, named 'Verlega', a name which in itself is allegorical since it is the Latinised substantive of the middle-Netherlandish word verlegen, which means weak, feeble, exhausted (Renger 1970:113). She has abandoned her spinning tools to listen to the man's music. A distaff at rest is a criticism of this undesirable behaviour identifiable as sloth (De Vries 2003:175). ${ }^{8}$ The 


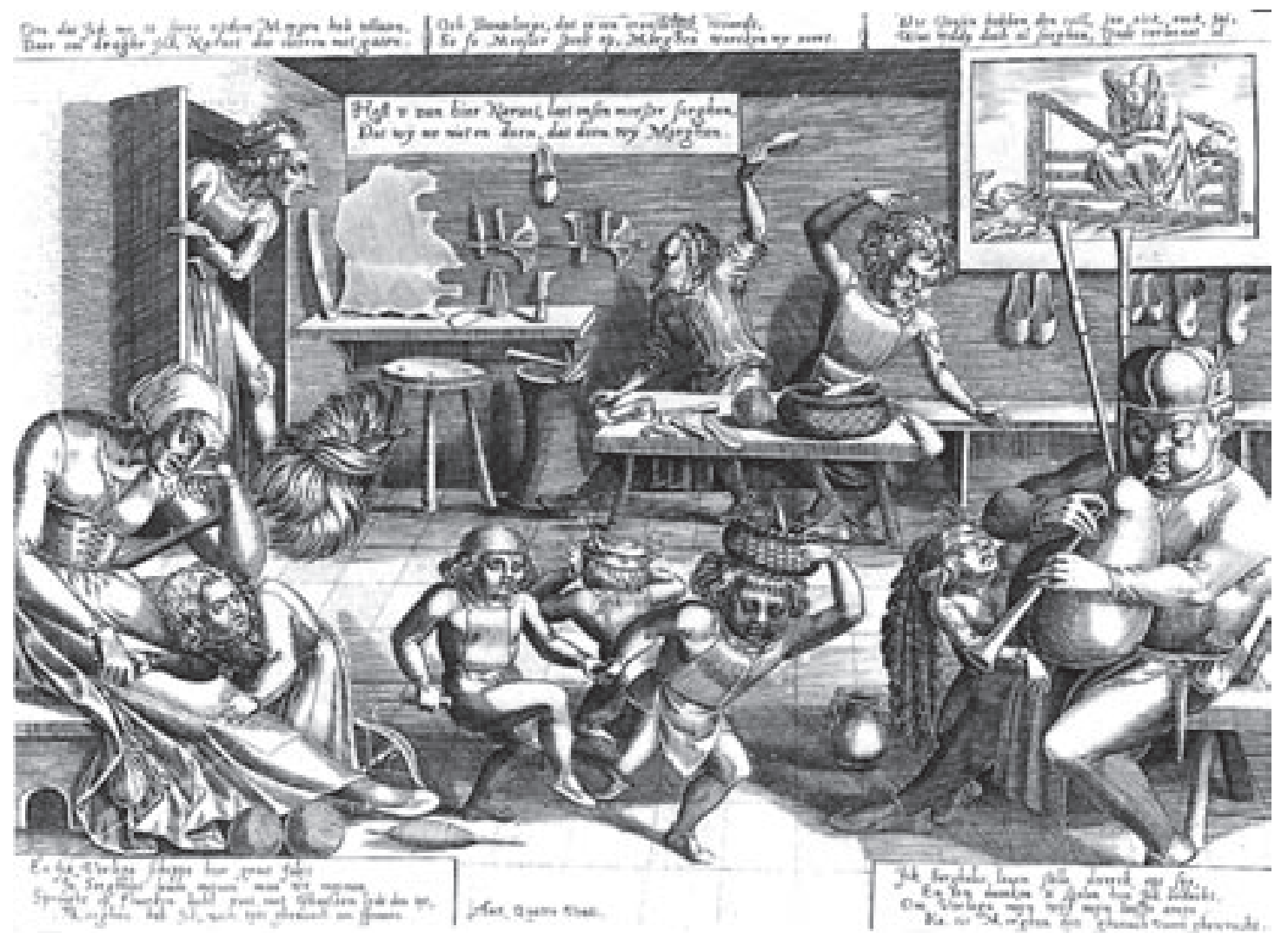

2 Pieter Baltens, Sorgheloos en Verlega. Copperplate engraving, 21,6 x 29,2 cm; plate 20,6 x 28,2 cm. Antwerp, Stedelijk Prentenkabinet, cat. III/B.6. (Moens 1994:133, cat. 89).

apprentices depicted in the background follow the bad example set by the protagonists by dancing to the bagpiper's music. The concept underlying this imagery is that poverty is mainly due to sloth. According to Liedtke (1984:238), 'drunkenness and gluttony go hand in hand with sloth in earlier and contemporary Dutch and Flemish literature ... where they were specified as causes of poverty.'

In line with this tradition, the behaviour of the woman in Ryckaert's painting could be interpreted as a reference to sloth and drunkenness, and the roaming pigs as symbols of gluttony. Although the young woman has not explicitly abandoned any spinning work, the notion of drunkenness is underpinned by her holding a beer-tankard. Like the dancing apprentices in Baltens's workshop, the carousing peasants in the background add to the general atmosphere of sloth and gluttony. But Ryckaert has introduced references to other vices as well. I have already mentioned the uninhibited lustfulness of the peasants, and there are more explicit allusions to the erotic nature of the situation: the flirtatious gesture of the young woman, the beer-tankard with its open lid, the earthenware pitcher in the foreground on the left flanking the table, the meat on the table, and the cobbler's feathered cap. Ryckaert has thus added the idea that excessive use of alcohol leads to illicit love. The association of a cobbler's workshop with sexual licentiousness can perhaps be linked to the ambivalent nature of the shoe. Not only is the shoe the professional symbol of the cobbler's trade (De Vries 2003:128), it also has erotic connotations. Shoes often play a role in amorous scenes where they are compared or related to women (De Jongh 1995:33, 74). ${ }^{9}$ But Ryckaert does not fail to warn the viewer against these vices. The owl perched on the shelf against the back wall functions as a comment on the foolish behaviour of people who abandon themselves to the transitory pleasures of alcohol and tobacco. Strategically placed on either side of the painting appears a cut branch with desiccated leaves, acting as vanitas symbols and supporting the warning against carnal pleasures (Van Haute 1999:7879). 
The only incongruous element in this picture is the figure of the sober cobbler. Despite the sexual advances made by the young woman, and oblivious to the peasants' drunken carousing he remains fixated on his work, strictly minding his own business. This could be interpreted as a literal illustration of the saying 'Schoenmaker blijf bij je leest' (Cobbler stick to your shoe-last). ${ }^{10}$ Perceived as self-conscious and relatively literate citizens, cobblers were notorious for their tendency to do the opposite (De Vries 2003:132-133). In Ryckaert's painting, however, the reprimanding tone of the saying is lost and the cobbler is represented as a neutral figure. Ryckaert's modification of the image of the cobbler from 'Sorgheloos', traditionally the target of scorn and ridicule, to a hard-working skilled craftsman may reflect the beginnings of a tendency to soften the satirical tone of the peasant genre.

Ryckaert was innovative in his choice of the theme of a cobbler in his workshop: neither Adriaen Brouwer nor David II Teniers, his main models and sources of inspiration, practised the genre before him. ${ }^{11}$ In devising his composition, however, Ryckaert did fall back on the tried and tested formula of his own speciality, the peasant picture. What Ryckaert did in the painting of The Cobbler was to substitute the main figure of the smoking, drinking, courting or music-playing peasant with its opposite, namely a hard-working artisan. As a result, the cobbler's serious working environment, identifiable as a workshop only by the tools of his trade, is invaded by elements associated with leisure and pleasure. The same situation occurs in the painting of The Smithy (3) probably produced in the same year. In this instance Ryckaert was not particularly creative in the conception. Again, he applied the recipe of the peasant picture, adding the imagery of a blacksmith in his workshop. Apart from the different equipment found in a smithy and the blacksmith's activity itself, the painting of The Smithy is more or less a repetition of the scene enacted in The Cobbler. No other representations of a smithy are known, which may indicate that Ryckaert himself was not genuinely attracted to the theme, or that the public had no interest in it. What these examples further demonstrate is that Ryckaert did not portray a cobbler or blacksmith's actual workshop, given that the interiors show such close affinity with one another and with other peasant interiors.

As a matter of fact, in his first depictions of the painter in his studio Ryckaert placed the artist in a similar peasant interior, pointing to his humble origins. In contrast with the skilled artisans, however, the painter is not associated

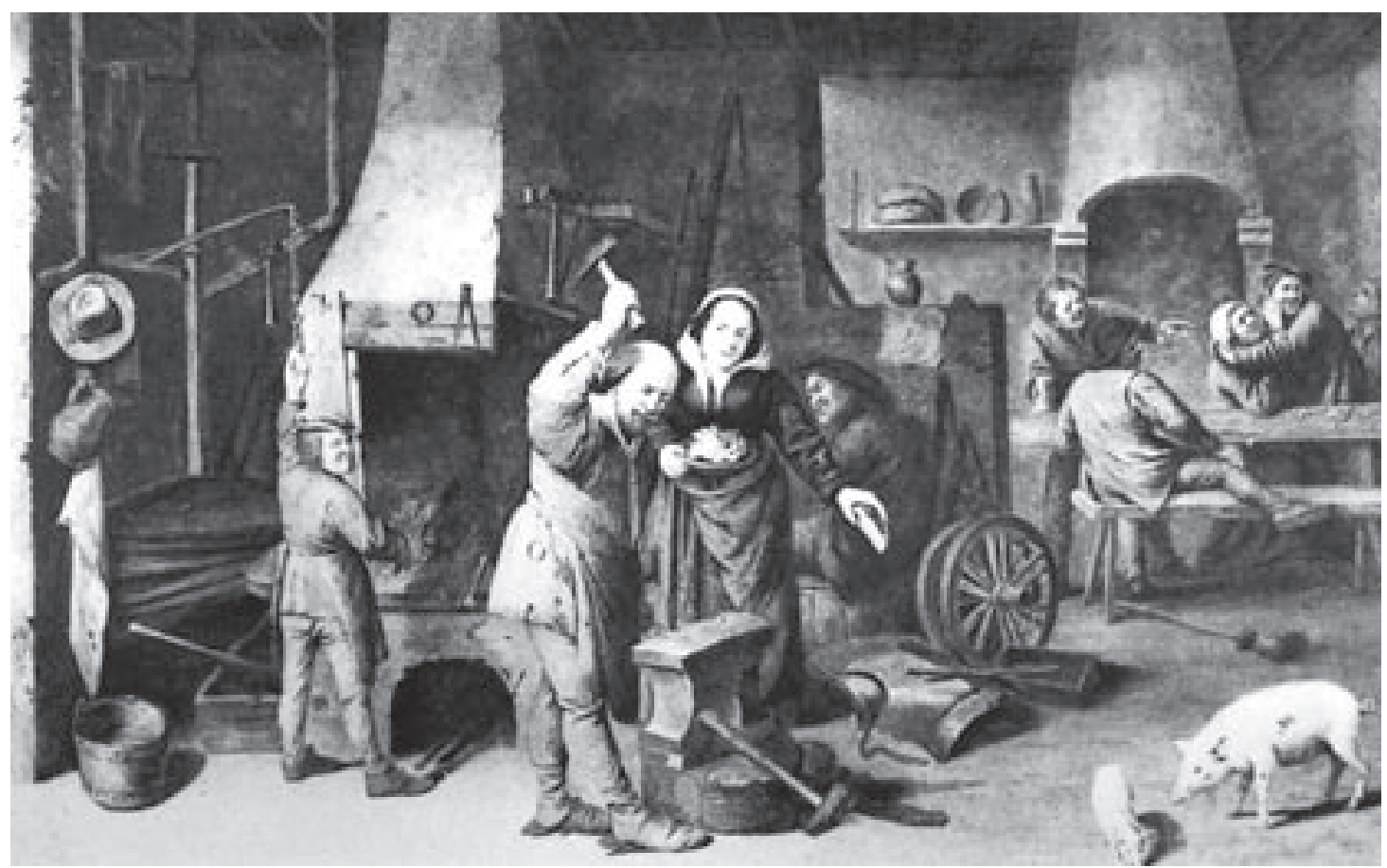

3 David III Ryckaert, The Smithy. Oil on panel, 64 x $75 \mathrm{~cm}$. Signed on piece of paper middle right: D RYC. f. Location unknown (Van Haute 1999, Cat. A15). 
with boorish peasants behaving badly. In The Painter's Studio (4) of 1636, all signs of questionable demeanour have been omitted. Although the artist himself is shown taking a break and lighting a pipe, a quiet atmosphere is maintained by the presence of a pupil who is drawing a plaster head, and the presence of a silent observer. In the 1638 version of Painter in his Studio with Model and Assisting Pupils (5), the emphasis on diligence is strengthened by the artist's concentration on his model, and the inclusion of a pupil and an assistant who is grinding colours. This gives the studio, despite its sober setting, a more prosperous air in tune with the artist's conspicuously elegant attire. These striking changes make it clear that Ryckaert wished to distance himself - and the profession of artist as an intellectual pursuit - from the lower class of mere craftsmen.

\section{Moderation of the peasant genre}

During the 1640s there was a general tendency among Flemish artists to enervate Brouwer's rude peasant scenes. Instead, these artists favoured 'a more courtly treatment, models

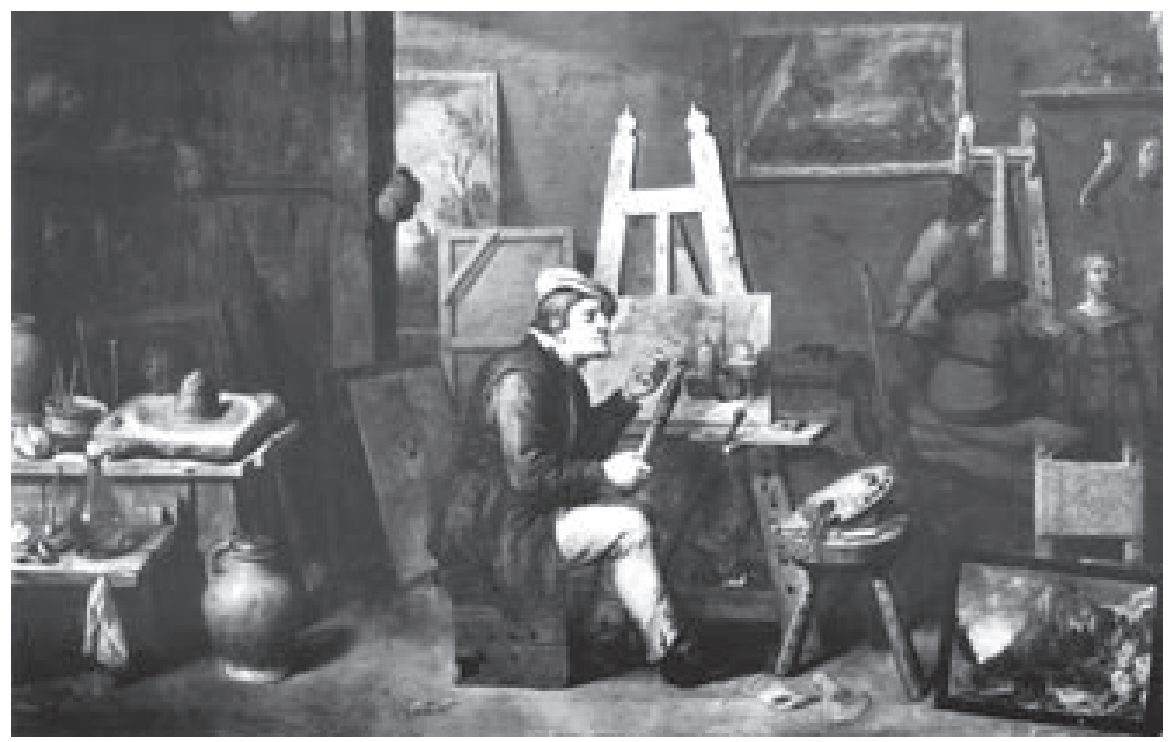

4 David III Ryckaert, Painter's Studio. Oil on panel, 41,3 x 62,2 cm. Signed and dated bottom left: D. Ryckaert 1636. Location unknown (Van Haute 1999, Cat. A1).

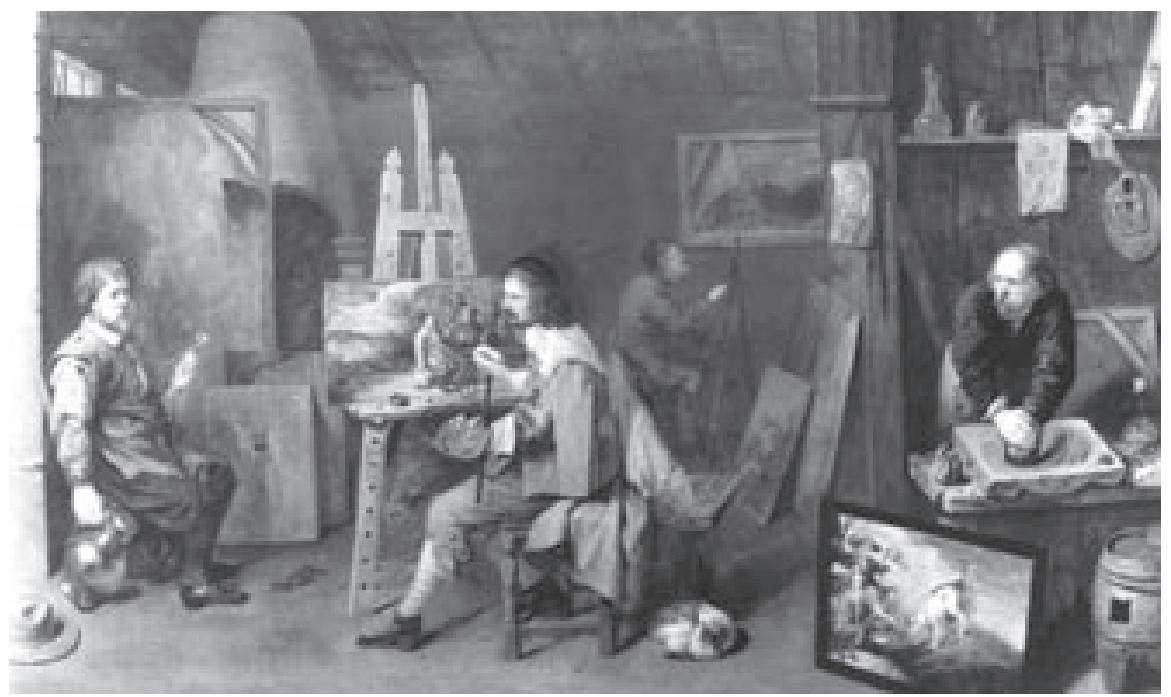

5 David III Ryckaert, Painter in his Studio with Model and Assisting Pupils. Oil on panel, $59 \times 95 \mathrm{~cm}$. Signed and dated on piece of paper upper right: D RYC f 1638. Paris, Louvre, inv. no. M.I.146 (Van Haute 1999, Cat. A18). Photograph Paris, RMN. Reproduced with kind permission of the museum. 
representative of a more genteel society, and a return to a clear and multicoloured palette' (Larsen 1985:318). ${ }^{12}$ This trend can be directly related to distinct changes in social patterns that had been spreading across Western Europe since the sixteenth century. One of these changes was in the status of the bourgeoisie (Dreher 1978:689). The city-based middle classes sought in growing numbers to transcend traditional class boundaries (Filipczak 1987:53-57). Opportunities for social advancement were dramatically multiplied and led to the emergence of an upper middle class which was eager to assume a more refined lifestyle (Wieseman in Sutton 1993-1994:187). Artists were closely involved in this gentrification process, also referred to as the 'civilising process'. ${ }^{13}$ They were, after all, the producers of the fine artworks which were sought after as marks of status and prestige (Filipczak 1987:55). ${ }^{14}$

In order to heighten his own status, Ryckaert needed to distance himself from the low-class rudeness of Brouwer. Hence he clad his next composition of $A$ Cobbler (6), executed around 1642 , in an atmosphere of diligence. As in The Cobbler of 1638, the working man is surrounded by the tools of his trade, but the furnishings in his workshop - especially the cupboard - are a vast improvement and indicate a certain wealth, distinguishing the cobbler's workshop from lowly peasant interiors. All symbolic references encountered in the 1638 version have vanished. Furthermore, the cobbler is represented without a female companion and as a bearded old man, worn by the human effort associated with industriousness (De Vries 2003:173). The motif of the chimney is still present, but the group of carousing peasants has been replaced with the still figure of a peasant seated in front of the burning fire. The artist's main concern is to express respect for the honest labour of this humble artisan. Ryckaert thus manifested himself as an important - if not leading - roleplayer in the process of moderating the peasant genre.

\section{The concept of joint labour}

The above type of iconography proved perhaps too stern for Flemish taste and in 1648 Ryckaert finally came up with a formula that proved popular with his clients. The painting of The Cobbler (7) in the Bally Schuhmuseum may have been his first attempt at an improved composition. The cobbler is now depicted in the company of a woman at work. Whereas she appears fairly young here, the woman seen in An Interior with a Cobbler (8) and in The Cobbler's Workshop of Mannheim ${ }^{15}$ is more readily identifiable as the cobbler's wife

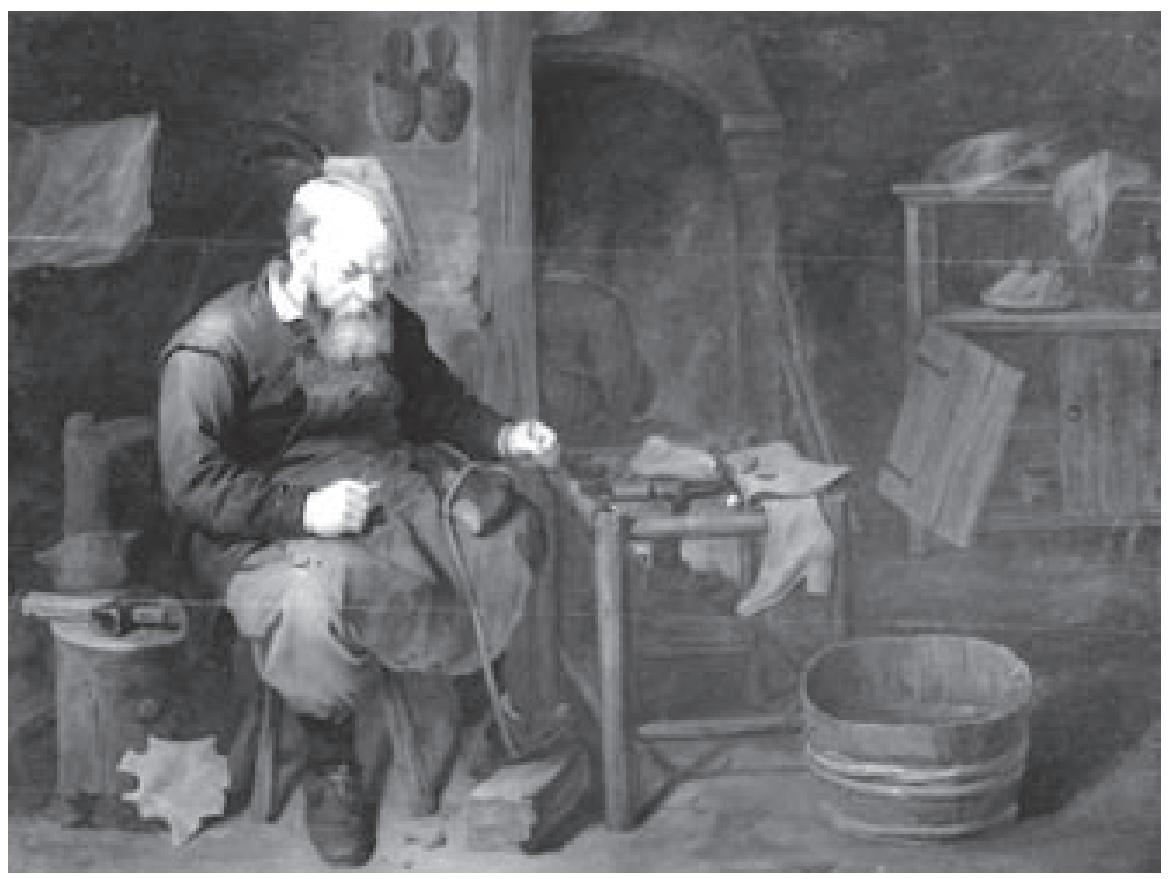

6 David III Ryckaert, A Cobbler. Oil on panel, 59 x 83,5 cm. Location unknown (Van Haute 1999, Cat. A52). 
due to her old age. The hunched postures of the figures betray not only their advanced age but also their lower social standing. ${ }^{16}$ Both their age and calm disposition, evident in the lack of extreme facial expressions and body language, preclude any connotations of a sexual nature. Complementing the image of the hard-working cobbler, the old woman is portrayed as an industrious spinster. In contrast with De Jongh (1967:65) ${ }^{17}$ and others ${ }^{18}$ who interpret the spinster as a symbol of the virtue of domesticity, De Vries rightly relates the image of the spinster to the virtue of industriousness. The process of spinning required human effort and resulted in financial gain. Especially among the lower classes, women's labour was the norm and their readiness to supplement the family income was considered praiseworthy (De Vries 2003:159, 166, 171-172).

It is possible that Ryckaert derived the idea of the spinning wife from the earlier mentioned engraving, by Pieter Baltens, of Sorgheloos

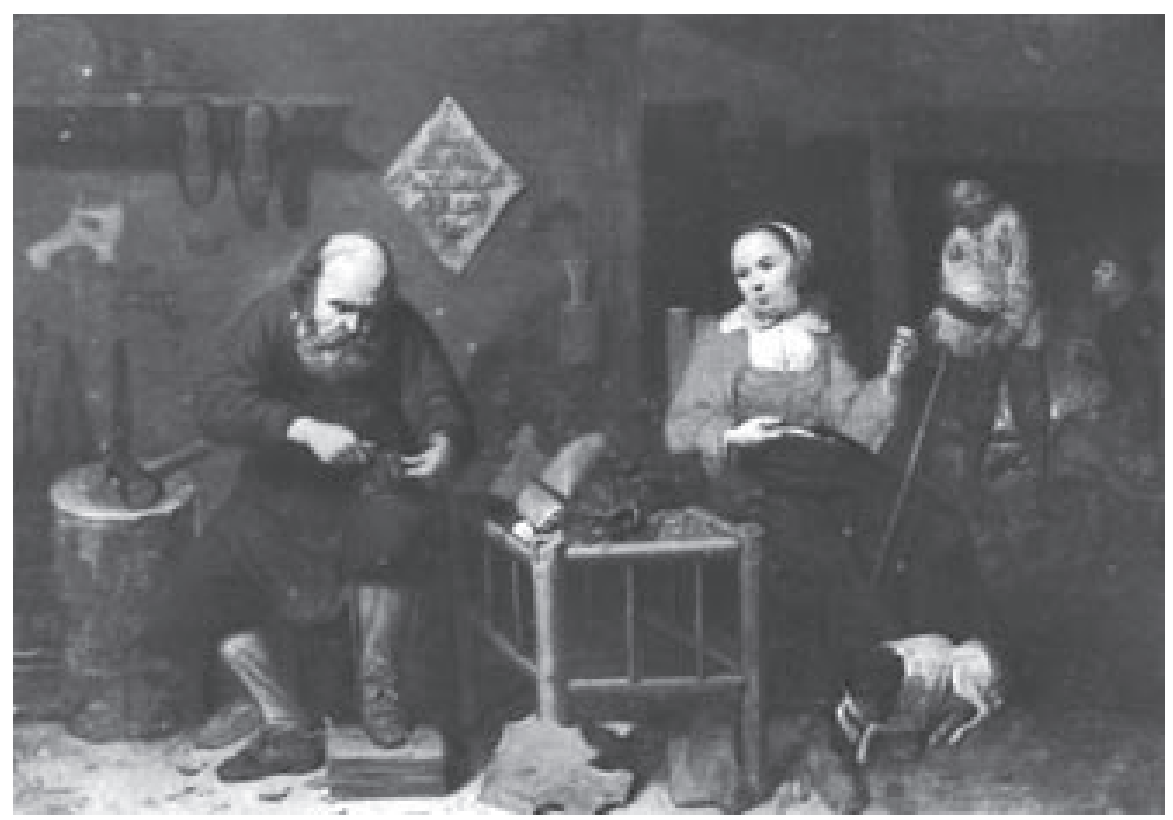

7 David III Ryckaert, The Cobbler. Medium and size unknown. Monogrammed bottom left: DR. Schönenwerd (Switzerland), Bally Schuhmuseum (Van Haute 1999, Cat. A73).

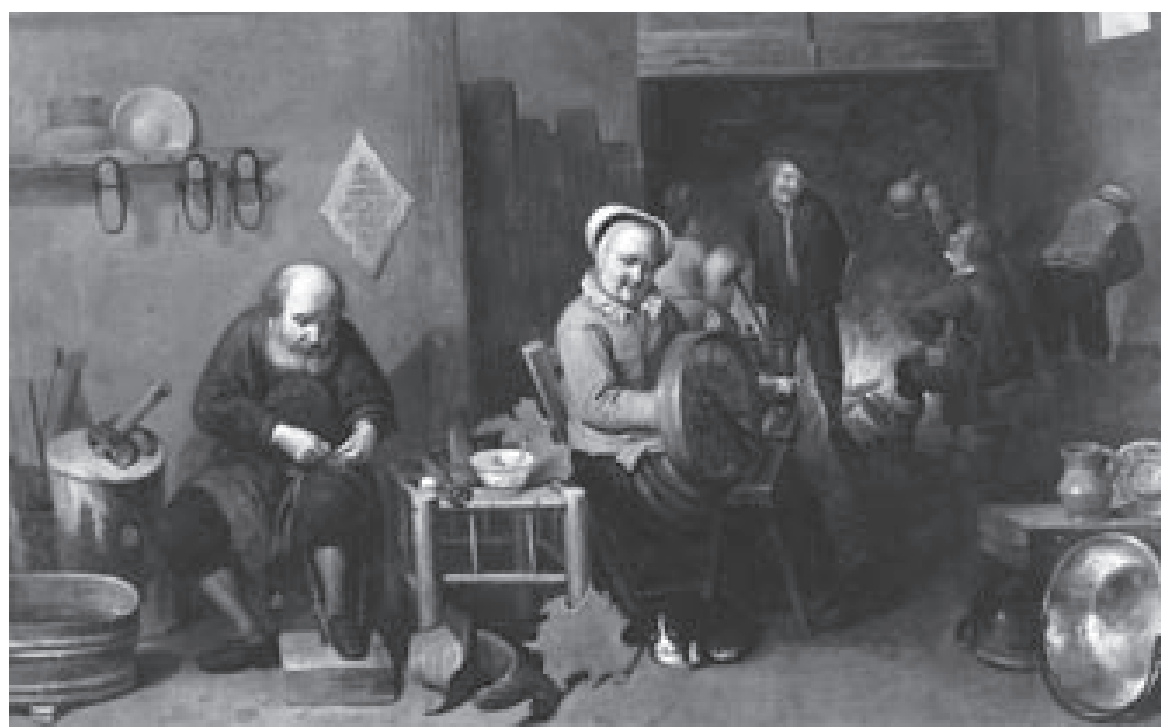

8 David III Ryckaert, An Interior with a Cobbler. Oil on canvas, 77,5 x $111 \mathrm{~cm}$. Location unknown (Van Haute 1999, Cat. A74). 
en Verlega. Yet, again, neither Ryckaert's cobbler nor his wife has laid down their tools. By adding the image of the spinning wife, the emphasis has shifted from a representation of the honest labour of the artisan to the joint effort of husband and wife to overcome financial difficulties and improve their living conditions. Ryckaert may have found his inspiration for this type of iconography in another literary source. The reference to joint labour is evident in the emblem Wat rust en ghewin from the Emblemata of Zinnewerck of Johan de Brune from 1624, a volume dedicated to Christian piety and virtues (De Vries 2003:168). The accompanying engraving by Adriaen van de Venne (9) shows striking similarities in the combination of an old man and woman at work. Of particular importance here is the image of the woman working a spinning wheel, with an open book lying in her lap. The text of the emblem praises the man and woman for earning a living together by means of their manual labour: 'How precious it is for God, how sweet for us to behold! That man and woman together provide for themselves, through their manual labour' (my translation). ${ }^{19}$ Although the correspondence in imagery between Van de Venne's engraving and Ryckaert's paintings does not necessarily imply a direct relationship between them, the emblem does confirm the current concern with joint labour as one of the mutual responsibilities within marriage.
What is interesting about these three paintings produced in the late 1640 s is the reappearance of the group of peasants gathered in front of the fireplace, wasting their time in idleness. The inclusion of the motif of the pisserken in An Interior with a Cobbler (8) further accentuates their baseness. As a background scene juxtaposing the main event, the motif underscores the artist's emphasis on virtuous behaviour leading to the social upliftment of the artisan class. At the same time it constitutes an object of ridicule to those better off than the foolish peasants.

In the two last pictures of the cobbler's workshop, produced in the late 1640s, Ryckaert prevented tedious repetition by altering the composition once again. In The Cobbler's Workshop of Kreuzlingen ${ }^{20}$ the cobbler is now seated on the right and his wife on the left, while the secondary group of peasants has been eliminated. In the monogrammed version of The Cobbler's Workshop (10), the cobbler uncharacteristically acknowledges the presence of his wife by looking at her. On the right-hand side, a young assistant has been included. His presence is indicative of the shoemaker's successful business, since these tradesmen often could not afford a servant (De Vries 2003:113, n. 4). It could thus be argued that Ryckaert related the success of the cobbler directly to his social status, prompting the artist to omit any references to boorish peasants.

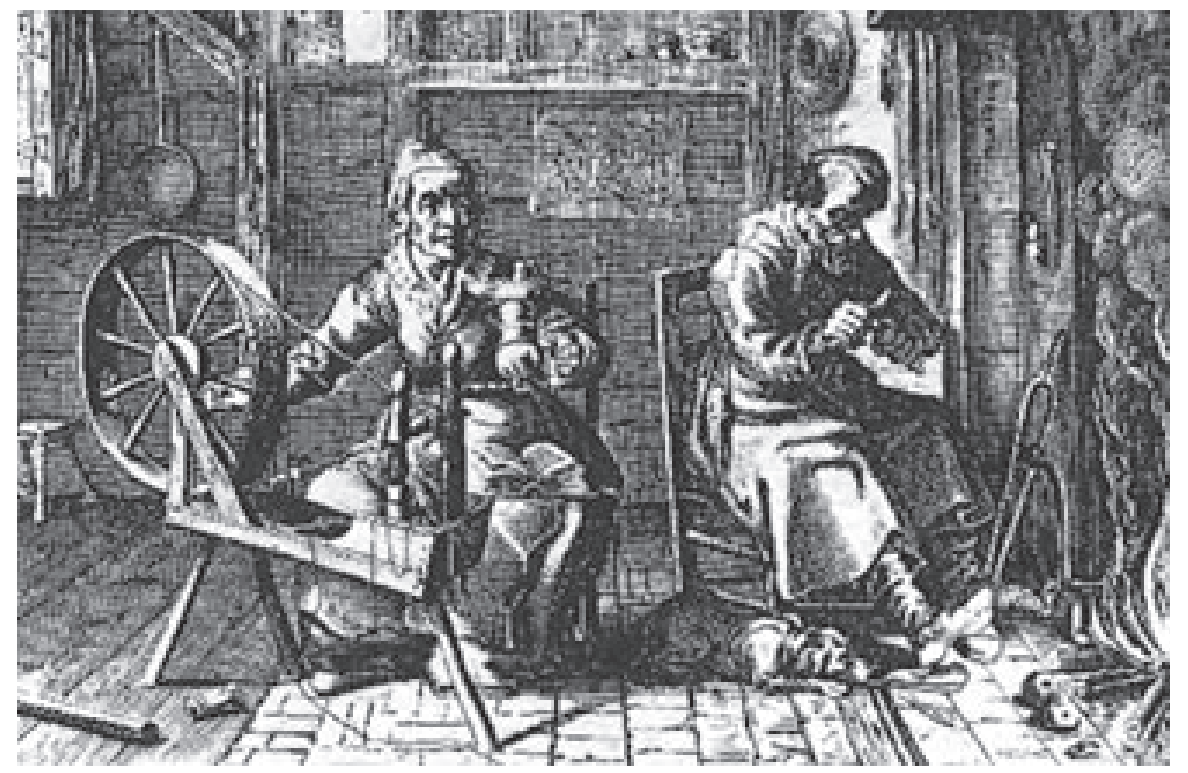

9 Adriaen van de Venne, Wat rust en ghewin. Engraving from the Emblemata of Zinnewerck of Johan de Brune, Amsterdam 1624 (De Vries 2003, fig. 187). 
This is again a reflection of the feverish social climate in which Ryckaert lived.

In the mid-1650s, Ryckaert painted the Amsterdam ${ }^{21}$ and Romans versions of The Cobbler's Workshop (11) and A Cobbler with his Friends in the Workshop of Leipzig. ${ }^{22}$ All three works share the motifs of the cobbler, his equally industrious assistant and again the group of drinking or gambling friends in the back. The motif of the spinster, on the other hand, undergoes several changes: she appears as the customary seated old woman in the Amsterdam painting; as the young woman seen before in the picture of the Bally Schuhmuseum but standing behind the cobbler in the Romans version; and has disappeared altogether from the scene in the Leipzig painting. These paintings are representative of the artist's later work in that they are a rather arbitrary amalgamation of earlier depictions of the same subject. It seems as if, by this stage, the artist had lost interest in the images' potential as visual signifiers. This was probably related to a decline in the popularity of the theme and a concomitant lack of market demand. ${ }^{23}$

\section{The alchemist in his laboratory}

Ryckaert's engagement with the concept of joint labour is also evident in his series of paintings representing an alchemist in his laboratory, also created in the late 1640s. The alchemist was a traditional theme in Netherlandish literature ${ }^{24}$ and in low-life genre prints, drawings and paintings, and can be traced back at least as far as Pieter Brueghel the Elder. ${ }^{25}$ During Ryckaert's time, the sixteenth-century perception of alchemy as a mysterious occupation still persisted, because alchemy was not based on scientific principles and escaped the dictates of reason (Van Lennep 1966:250). Despite the fact that some of these pseudo-scientists did in fact contribute to learning (Sutton 19931994:420), the literary and pictorial traditions invariably treated alchemists as figures of scorn and folly. The profession usually served as a pretext to ridicule human behaviour by stressing the vanity of this absurd enterprise. ${ }^{26}$ In his first painting of The Alchemist (12) of c.1642, Ryckaert represents the alchemist at work in his laboratory, in very much the same manner as $A$ Cobbler (6). However, the impression of serious study is undermined by the inclusion of

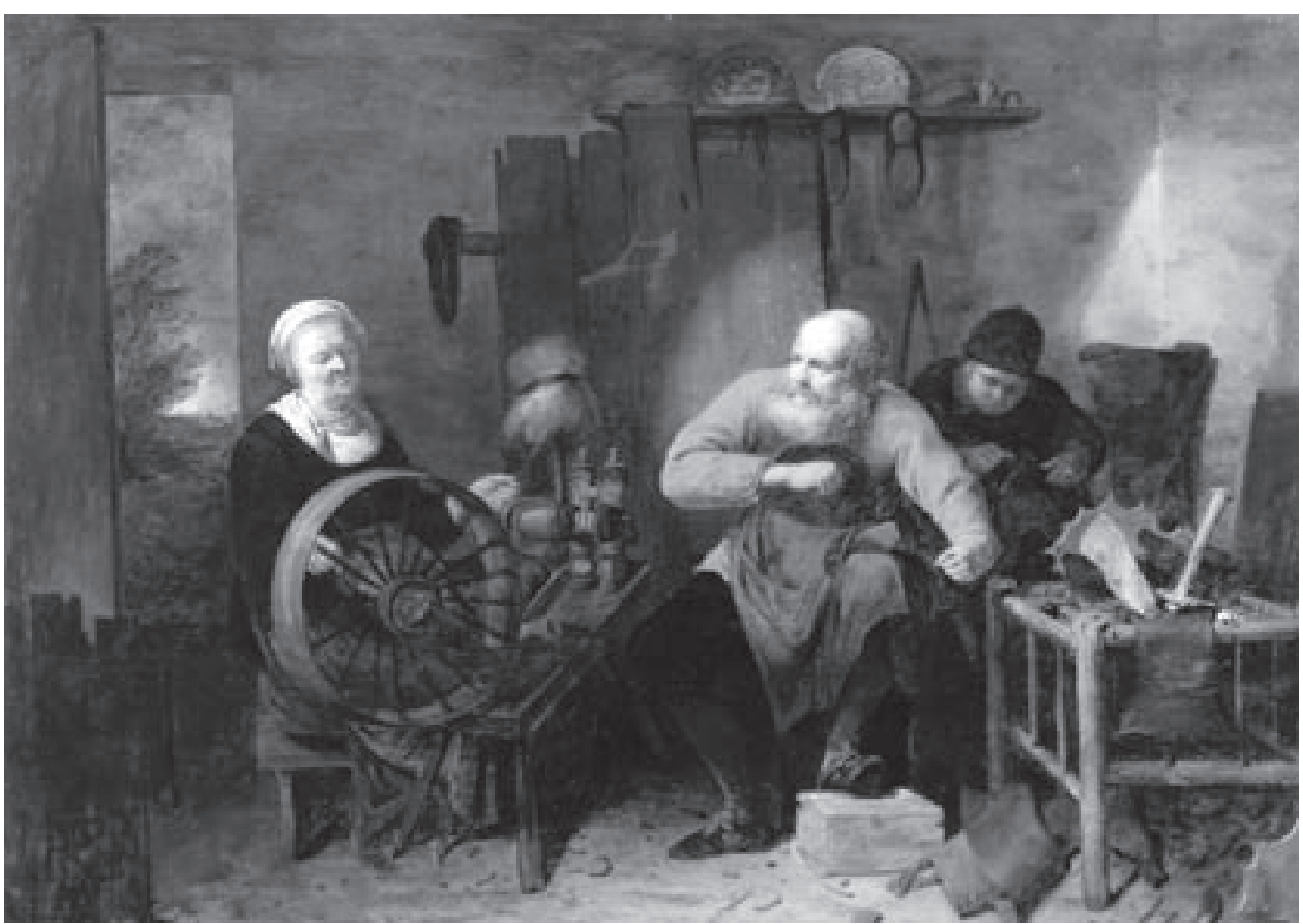

10 David III Ryckaert, The Cobbler's Workshop. Oil on panel, 53,5 x $73 \mathrm{~cm}$. Indistinctly monogrammed bottom left. Location unknown (Van Haute 1999, Cat. A77). 
a little owl as a reference to man's foolishness. This makes it clear that Ryckaert shared the widespread perception of the alchemist as an image of meaningless and futile activity.

In the late 1640s, Ryckaert chose to represent the alchemist in the company of his wife, in accordance with his contemporary depictions of cobblers. The paintings are The Alchemist of Le Havre, ${ }^{27}$ The Alchemist in his Laboratory of Brussels, ${ }^{28}$ The Alchemist with his Wife in the Workshop of Leipzig,, ${ }^{29}$ and an exact copy thereafter (13). The interior is clearly recognisable as a laboratory by the alembic being heated on a small oven. The alchemist himself sits in front of a fireplace while his implements, such as metal containers, ceramic pots, glass bottles, bellows and retorts fill empty corners. The alchemist's wife, however, is not working but reading. Like the woman in the engraving by Adriaen van de Venne, she has an open book in her lap. She is shown at the moment when she actually interrupts the alchemist in his work to draw his attention to a passage in the book which, in the present context, can only be interpreted as the Bible. ${ }^{30}$ Instead of adding the blatantly symbolic little owl, Ryckaert directs a subtle warning via the alchemist's wife to the viewer against the risk of losing all one's possessions, if not one's spiritual wellbeing, in the pursuit of profit.

In these depictions of both cobblers and alchemists the women play an equally important role in the process of labour, by supporting their husbands. The cobbler's wife does so by spinning and hence effectively contributing to the income, while the alchemist's wife has more of a coaching role; that is, keeping her husband on the right track. The reason why the image of the alchemist is not tainted by the presence of the idle peasantry may be found in the more intellectual nature of his work. Yet the ambiguity of alchemy is hinted at by the wife, rendering the profession less prestigious than that of, for example, the painter in his studio. Coming back to this theme, it should be noted that the painter's wife is never present in his studio. As mentioned earlier, women's labour was acceptable practice only among the lower classes. By presenting the painter working independently and undisturbed, Ryckaert once again affirmed his individual and professional identity as socially superior.

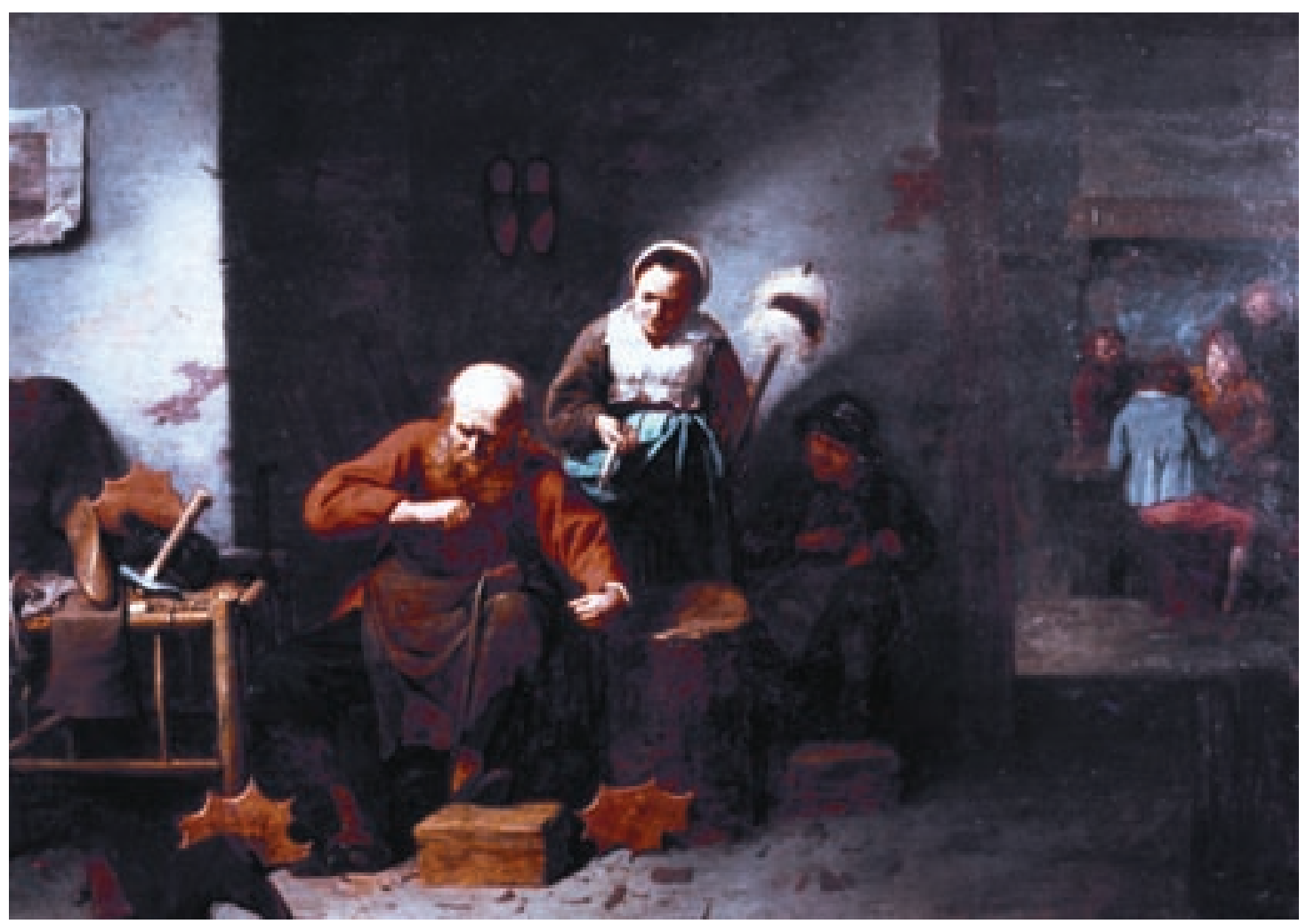

11 David III Ryckaert, The Cobbler's Workshop. Oil on panel, 55,5 x $75 \mathrm{~cm}$. Signed bottom right: D Ryckaert. Romans, Musée international de la Chaussure, inv. no. 85.16.1. (Van Haute 1999, Cat. A138). 


\section{Ryckaert's interest in the theme of labour}

After having considered how Ryckaert viewed the representation of labour in his works, the question remains why the artist would have deemed the theme of a cobbler in his workshop worthy of representation. Based on a long pictorial and literary tradition, the theme of the cobbler's workshop can be traced back to Pliny's Naturalis Historia, more specifically to Pliny's reference to Piraeicus, a famous painter of small things. The ancient example of Piraeicus served to demonstrate that 'low and dirty subjects' such as barbers' shops, cobblers' workshops, donkeys, fish, meat, poultry and the like offered the possibility of fame and were particularly enjoyed by a public that was prepared to pay high prices for them. Pliny's description turned the minor pictura into a legitimate pictorial speciality. Painters of the early modern period who chose 'low subjects' thus emulated a famous ancient painter and were known as rhyparographi or, as Karel van Mander called them, schilders van cleen beuselinghen (painters of small

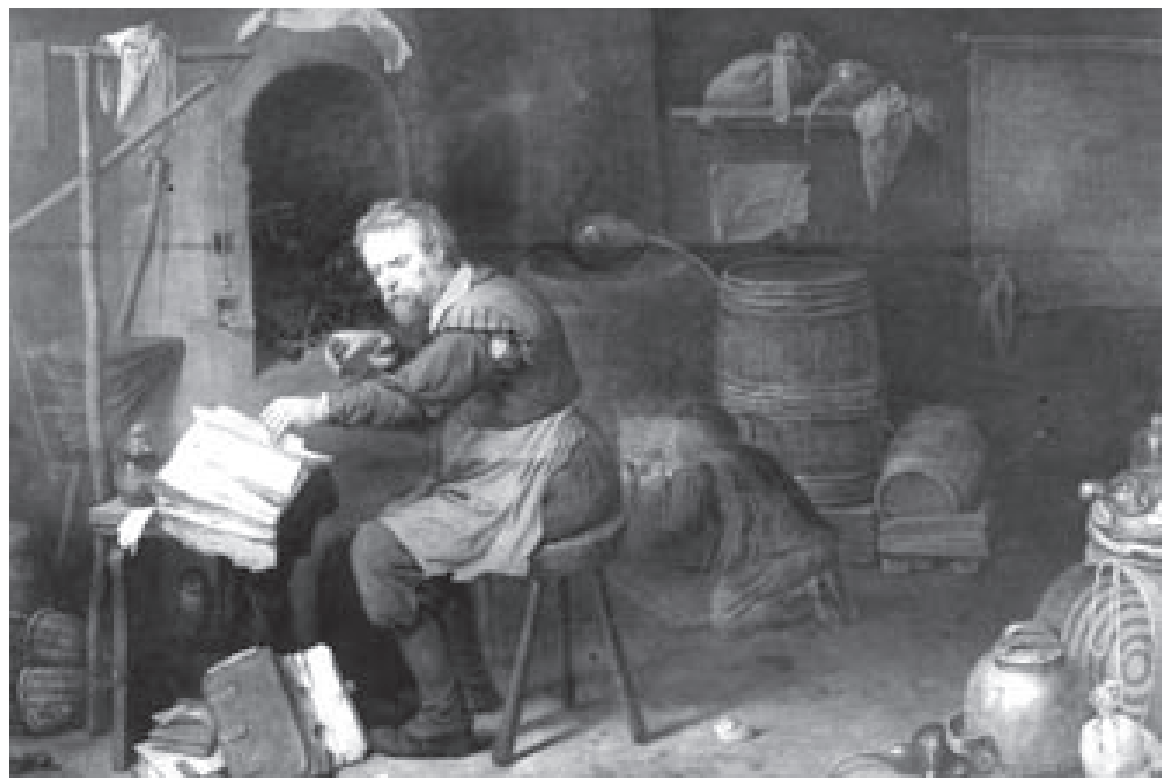

12 David III Ryckaert, The Alchemist. Oil on canvas, 60,5 x 80,5 cm. Budapest, Szépmüvészeti Múzeum, inv. no. 595 (Van Haute 1999, Cat. A53). Reproduced with kind permission of the museum.

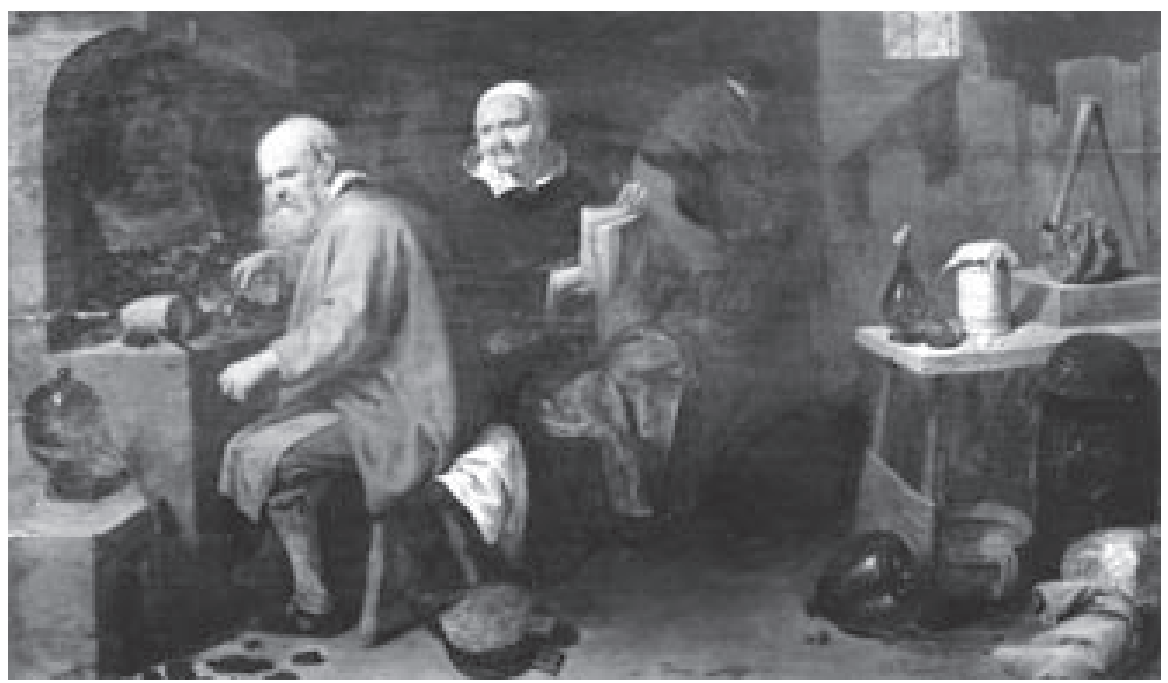

13 David III Ryckaert, The Alchemist with his Wife in the Workshop. Oil on panel, 40,6 x 62,2 cm. Signed and dated bottom right: D.Ryckaert 1649. Location unknown (Van Haute 1999, Cat. A81). 
dirty things) (De Clippel 2006a:42, 358). In his representations of cobblers and barbersurgeons, as seen in The Foot Operation (14), Ryckaert depicted 'small dirty things' in the sense that the subjects belonged to the world of the low classes. He matched the lowliness of the theme with a 'low' style characterised by sombre tonalities in an effort to imitate reality (De Clippel 2006a:57).

While this explains the suitability of the theme as a worthy subject, more compelling reasons may account for the artist's interest in the theme of labour. De Vries states that, as providers of basic products, artisans such as the cobbler, the blacksmith and the butcher delivered services that were vitally important to the entire population. She argues that the high frequency and long history of these basic trades may explain the rich imagery dedicated to them in the domain of visual arts. When this pictorial tradition reached a peak in the second half of the seventeenth century, its praise for the early modern virtue of Diligentia resonated ever so strongly (De Vries 2003:123-125). In the Southern Netherlands, however, the theme of labour was not as popular as in the North. Ryckaert was the only painter in Antwerp who specialised in the representation of men at work - particularly cobblers. His choice was not motivated by any business or possible family relationships with these artisans ${ }^{31}$ because his paintings do not qualify as portraits - not even genre portraits. ${ }^{32}$ His men at work never look at the viewer nor do they address anyone else represented in the painting. Their faces are, to a certain degree, individualised but become stereotyped due to repetition. It seems likely, therefore, that conditions prevailing in the art market drove Ryckaert to make the depiction of men at work his field of specialisation. The artist introduced this type of picture as one of his specialities, which would then be equated with his name. He would then try to exploit the type for as long as possible and make changes when deemed necessary to ensure the continued patronage of a larger and more reliable clientele (Van Haute 1999:27). It turned out that he did gain a certain reputation for these paintings, which led him to produce multiple versions. The existence of copies after the artist's works ${ }^{33}$ further testifies to the public demand for cobbler paintings.

Who were his clients? Would a cobbler have commissioned a depiction of a workshop interior? Despite the modest and often even

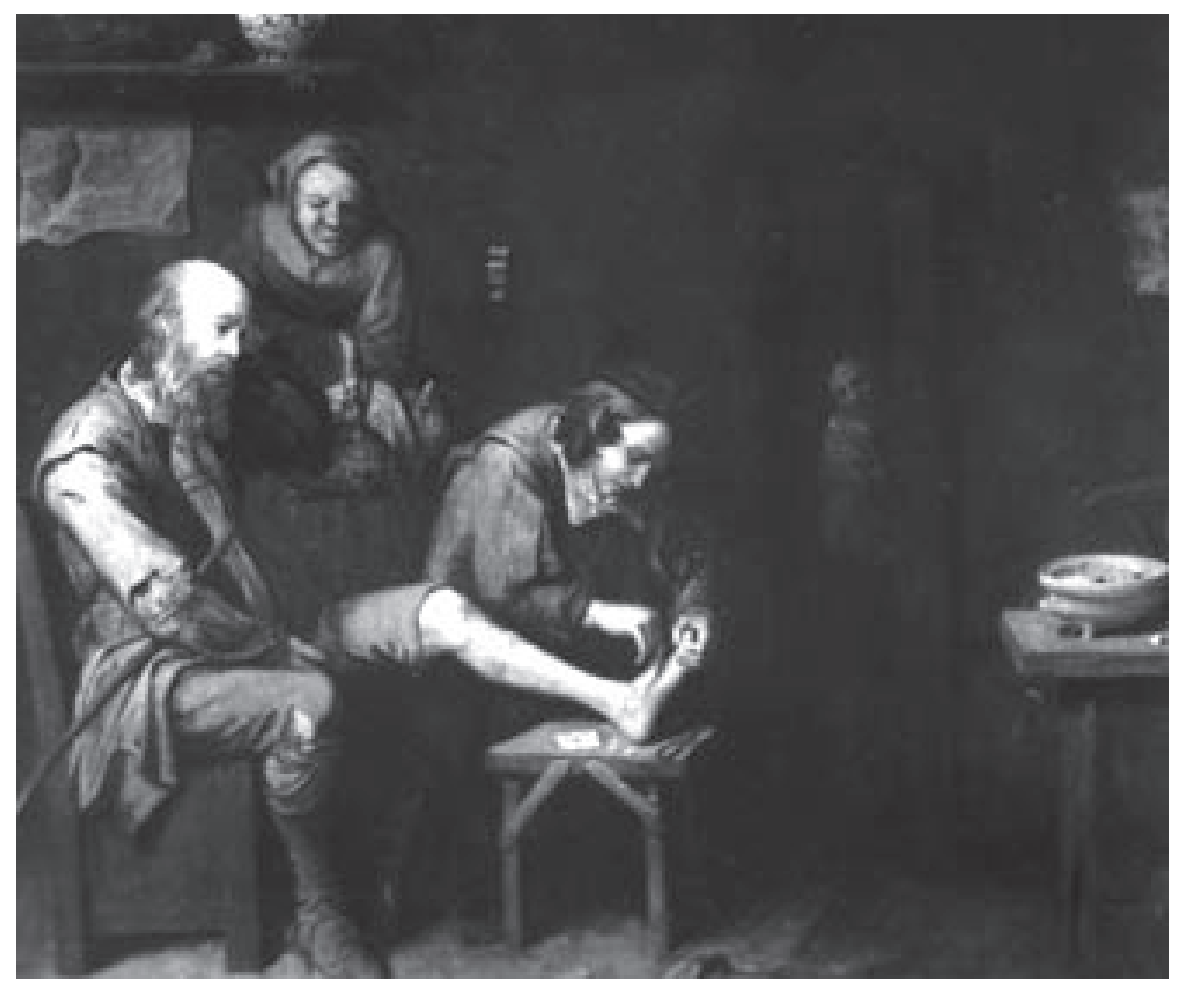

14 David III Ryckaert, The Foot Operation. Oil on canvas, 54 x $66 \mathrm{~cm}$. Monogrammed bottom left: DR. Location unknown (Van Haute 1999, Cat. A123). 
poor living conditions of many a cobbler, it appears that some could spare the money for the purchase of paintings and prints (De Vries 2003:131). De Vries's investigation of Antwerp inventories from the period 1600-1680 led to the discovery of five cases of cobblers or their widows who possessed small collections of paintings. An example is the estate inventory of Anna van Lijere, widow of the cobbler Peter Joris, and wife of (again) a cobbler, Janne van Kelst, drawn up in 1633. It lists 21 paintings, two of which were portraits of the widower and his deceased wife. This shows that even shoemakers had their portraits made. Furthermore they owned 13 'leesboecxkens' (small reading books), indicating a certain literacy among this type of craftsmen (De Vries 2003:134). The inventory of Jacques Riems, 'schoenmaker', who died on 1 May 1656, is more modest as it lists only five paintings: two landscapes, a Caritas painting, an evening meal and a 'Sint Janneken' (Duverger 1993:220, no. 2072). What can be concluded from this investigation into the art inventories of cobblers is that only a limited number of these artisans were prosperous enough to even have an inventory drawn up. ${ }^{34}$ Moreover, the existing inventories fail to mention a single cobbler's workshop. The bare walls seen in Ryckaert's depictions of a cobbler's workshop therefore seem to confirm the fact that the average cobbler could not afford to commission or buy such paintings. ${ }^{35}$

Paintings of artisans' workshop interiors do, however, appear in various inventories of the wealthy bourgeoisie. De Vries mentions the example of the Antwerp citizen Jan Baptista I Courtois (Lord of Gortes, Ter Zalen and other properties) who was the owner of 'een stuxken Schoenlapper' (Duverger quoted in de Vries 2003:135). Although this does not necessarily exclude other citizens as owners of such paintings, it does lend credibility to the perception that Ryckaert's paintings were directed at the upper echelons of society, for their edification and amusement.

On this point, I suggest that Ryckaert's pictures display the two components identified by Eddy de Jongh (1995:83-103) as characteristic of genre painting: to instruct and entertain. In Het Gulden Cabinet of 1661, his Flemish contemporary Cornelis de Bie, whose account of David Ryckaert is particularly perceptive and accurate, already commented explicitly on the didactic component in
Ryckaert's oeuvre: 'Furthermore, his science manages to execute other witchcraft scenes and strange adventures so artfully, that this can only come from his hand, if it has particular virtue and vitality for the instruction of the youth' (my translation and italics). ${ }^{36}$ De Bie draws attention to the two important components which make up an artist's talent, namely his scientific knowledge (sijne wetenschap) and his creative skills (constich). The emphasis on virtue (deught) is made explicit, as is the artist's aim to instruct the youth. Ryckaert's mode of instruction was, however, not emphatically moralising but more entertaining in a Brueghelian comic manner. The comic/ satirical element functioned as a pictorial tactic that allowed his 'realist images to perform their normative work' (Westermann 2002:361).

\section{Conclusion}

In his portrayal of labour, Ryckaert applied a formula derived from his paintings of drinking, smoking, courting and gambling peasants. However, like the works of his colleagues in the Northern Netherlands, ${ }^{37}$ his paintings of artisans' workshop interiors must be interpreted as expressions of the early modern civic virtue of industry and diligence (De Vries 2003:135). In the earlier representations which are still rooted in traditional iconography related to the peasantry, the milieu of the craftsman is openly subjected to criticism. The artisan himself, on the other hand, is always seen at work, the focus being on the process of labour, not the end product. The cobbler is represented as the prototype of the artisan: hard working, poor but honest, and an example to others (De Vries 2003:122, 137). By choosing this iconography, Ryckaert established the craftsman's professional identity in visual form without the active input of the artisans themselves or their guild. ${ }^{38}$ Starting in the early 1640s, he made a genuine effort to improve the professional image of the craftsman by eliminating blatant derogatory references. Later on he also added the motif of the artisan's spinning wife to demonstrate the virtue of the joint labour of the working-class couple. As such the iconography exemplifies the saying 'Arbeid adelt' (Labour ennobles). His efforts to refine his subject matter were in line with a general tendency in Flanders towards social upliftment, fuelled by the Christian-humanist idea that only hard work leads to social 
improvement and prosperity, to the benefit of society as a whole. But, at the same time, Ryckaert remained faithful to the satirical nature of the peasant genre. By juxtaposing the hard-working man and his wife with a group of idle peasants as exemplars of human depravity, carnality and foolishness, the artist reminded the viewer of the fundamental baseness of the labouring class. He thus made sure to keep the artisan in his place on the social ladder, close to the peasantry. Moreover, the more respectful treatment of professions of a more intellectual nature - the artist, the alchemist - reflects the artist's self-consciousness and his acute awareness of social differentiation on the basis of professional identity. Knowing that Ryckaert produced these paintings for a higher social class to which he himself belonged, it is clear that he shared his clients' desire to consolidate and justify the social order. Moreover, by using his art 'tot leeringh vande jeught' (to instruct the youth), he actively contributed to the shaping of social norms and values.

\section{Notes}

1 This article was first published in De Zeventiende Eeuw, Jaargang 23, 2007,no.2. I would like to thank Maarten Prak for allowing me to re-publish this extended version of a paper read at the $22^{\text {nd }}$ Conference of the Werkgroep Zeventiende Eeuw, held at the Internationaal Instituut voor Sociale Geschiedenis (IISG) in Amsterdam on 1 September 2006. I also wish to express my gratitude to Annette de Vries, Alison Kettering, Karolien de Clippel and Katlijne van der Stighelen for their valuable advice and assistance.

2 The term 'peasant' (boer) designates not only farmers and country folk, but also anyone considered uncultivated and uncouth in appearance, deportment or speech.

3 Jan Muylle (in Vekeman and Müller Hofstede 1984:139) states that the appreciation of peasant scenes of diverse masters was widespread during the seventeenth century up to ca. 1700 among the circles of the bourgeoisie and high-ranking prominent citizens, the artbuying public.

4 For a list of sources on the origin of the peasant genre, its iconography and social function, see Van Haute (1999:225, notes 13 and 14).

5 Veldman (1992:264) interprets the iconography of 'the many popular images of beggars and poor, drunken and otherwise delinquent peasants and shabby folk ... [as] a clear warning against squandering time'.

6 De Vries (2003:116) maintains that the cobbler merely repairs shoes, but the presence of the last and the pieces of new leather show that he fashions new shoes.

7 See, for example, Quiringh van Brekelenkam's The Cobbler's Workshop (De Vries 2003, fig. 112) and David II Teniers' The Cobbler (De Vries 2003, fig. 115).

8 The motif of the sleeping spinster as a symbol of sloth also appears in Ryckaert's oeuvre, for example in the Kitchen Interior with Sleeping Old Woman (oil on canvas, $74 \times 94 \mathrm{~cm}$. Signed and dated bottom centre (?). Location unknown) (Van Haute 1999, Cat. A166).

9 De Jongh (1995:34) mentions, among other examples, the expression 'iemands oude schoen' (someone's old shoe) which refers to a woman who has already been someone's lover. In Ryckaert's painting, however, the shoes displayed on the floor do not evoke any such particular idiom.

10 De Vries (2003:133) also elaborates on a pictorial equivalent of the saying in the representation of the story of Apelles and the cobbler. The fact that this story was painted by Frans Francken the Younger around 1610-1615 (De Vries 2003, fig. 138) shows the popularity of the motif in early modern Flanders. Ryckaert's cobbler, however, does not relate directly to this story.

11 David II Teniers' The Cobbler (De Vries 2003, fig. 115 ) is the only known painting by this artist of the subject. Although it is not dated, it may well have been produced after Ryckaert created his first version.

12 See also De Clippel (2006b:29-30, 34).

13 De Clippel (2006b:29, n. 45) adopts the term 'civilizing process' from N. Elias. 1982. Het civilisatieproces: sociogenetische and psychogenetische onderzoekingen, 2 vols. Utrecht and Antwerp.

14 For an expanded discussion see Van Haute (1999:19).

15 David III Ryckaert, The Cobbler's Workshop. Oil on panel, $58,5 \times 78 \mathrm{~cm}$. Signed bottom right: D.Ryckaert. Mannheim, Reiss-Museum der Stadt Mannheim, inv. no. Staat 264 (Van Haute 1999 Cat. A75).

16 For a discussion of postures, gestures and disposition as a means of social distinction, see, for example, Roodenburg (in Franits 1997:175186).

17 De Jongh (1967:65) states that the image of the spinster is, on the one hand, derived from the parable of the Wise and Foolish Virgins, and on the other hand it is based on Chapter 31 of the Proverbs of Solomon: 'Lof der deugdzame huisvrouw.' He maintains that the spinning woman remained the symbol of the virtue of domesticity until the end of the seventeenth century.

18 See De Vries 2003:159-160, n. 31. 
19 'Hoe kostlick is 't, voor God, hoe zoet, voor ons, 't aenschouwen! Dat man en vrouw te zaem haer zelven onderhouwen, Van haerer handen werck' (quoted in de Vries 2003:168).

20 David III Ryckaert, The Cobbler's Workshop. Oil on panel, $72 \times 85 \mathrm{~cm}$. Kreuzlingen (Switzerland), Dr Gerlinde Kisters (Van Haute 1999, Cat. A76).

21 David III Ryckaert, The Cobbler's Workshop. Oil on panel, $53 \times 69 \mathrm{~cm}$. Amsterdam, Rijksmuseum, inv. no. A 357 (Van Haute 1999, Cat. A137).

22 David III Ryckaert, A Cobbler with his Friends in the Workshop. Oil on panel, 40,7 x $49 \mathrm{~cm}$. Signed bottom right: DAVID.RYKA(RT?). Leipzig, Museum der bildenden Künste, inv. no. I.351 (Van Haute 1999, Cat. A139).

23 De Clippel (2006b:31) states that after the middle of the century, the fall in purchasing power of the Antwerp citizens, combined with changing tastes, severely reduced the market for genre painting.

24 Numerous emblems were devised in the sixteenth and seventeenth centuries to admonish the alchemist's costly folly (see Henkel and Schöne 1967).

25 For a bibliography on the alchemist theme, see Sutton (1993-1994:422, n. 1).

26 For an extended discussion, see Van Haute (1999:34-35).

27 David III Ryckaert, The Alchemist. Oil on canvas. Signed and dated bottom centre: D.Rijckaert 1648. Le Havre, Musée des Beaux-Arts André Malraux, inv. no. 77-19 (Van Haute 1999, Cat. A78).

28 David III Ryckaert, The Alchemist in his Laboratory. Oil on canvas, $66 \times 87,5 \mathrm{~cm}$. Signed and dated bottom centre: D.Rijkar... f 1648. Brussels, Koninklijke Musea voor Schone Kunsten van België, inv. no. 156 (Van Haute 1999, Cat. A79).

29 David III Ryckaert, The Alchemist with his Wife in the Workshop. Oil on panel, $42 \times 62 \mathrm{~cm}$. Signed and dated bottom centre: D. Ryckaert $f$. Leipzig, Museum der bildenden Künste, inv. no. I.350 (Van Haute 1999, Cat. A80).

30 Müller (1978:152) explains that the ambiguous character of alchemy rendered it suspect and, in the eyes of the church, sometimes sacrilegious.

31 This is another motif suggested by De Vries (2003:137) for the production of genre portraits or genre paintings with a portrait allure.

32 For a definition of the genre portrait, see Wieseman (in Sutton 1993-1994:182-193).

33 So far seven are known (see Van Haute 1999:162, 172-173).

34 This would seem to seriously compromise, if not invalidate, Giorgio Vasari's remark made a century earlier about the extensive painting production in the southern Netherlands: that there was no cobbler around who did not have a small 'Duits' landscape (quoted in De Vries 2003:132)

35 Another possibility is that the Antwerp cobblers' guild was somehow involved in the production of workshop interiors (see De Vries 2003:125130). In the absence of any supporting evidence, I prefer to suggest that Ryckaert worked independently from the guild.

36 'Voorts ander toovery en vremde aventuren, weet sijne wetenschap soo constich uyt te vueren, dat niet van hem en compt, oft 't heeft besonder deught en t' levens crachten in tot leeringh vande jeught' (De Bie 1977:311).

37 De Clippel (2006b:33) confirms that 'despite political separation and religious antagonism, the stream of exchanges and cross-fertilization' between the northern and southern Netherlands continued throughout the seventeenth century.

38 De Vries (2003:135) admits that artisans' workshop interiors remain isolated from the professional identity of the relevant craftsmen.

\section{References}

De Bie, C. 1971. Het Gulden Cabinet van de edel vry Schilderkonst [1661]. Facsimile ed. with introduction by G. Lemmens. Soest: Davaco Publishers.

De Clippel, K. 2006a. Joos van Craesbeeck (1605/06 - ca.1660). Een Brabants genreschilder. 2 vols. Turnhout: Brepols.

-. 2006b. Two sides of the same coin? Genre painting in the north and south during the sixteenth and seventeenth centuries. Simiolus 32(1):17-34

De Jongh, E. 1967. Zinne- en minnebeelden in de schilderkunst van de zeventiende eeuw. S.I.: Openbaar Kunstbezit in Vlaanderen.

-. 1995. Kwesties van betekenis. Thema en motief in de Nederlandse schilderkunst van de zeventiende eeuw. Leiden: Primavera.

De Vries, A. 2003. Ingelijst werk. De verbeelding van arbeid en beroep in de vroegmoderne Nederlanden. Doctoral thesis, University of Amsterdam.

Dreher, F. P. 1978. The artist as seigneur: Chateaux and their proprietors in the work of David Teniers II. The Art Bulletin 60:682-705.

Duverger, E. 1993. Antwerpse kunstinventarissen uit de zeventiende eeuw. Fontes historiae artis neerlandicae. Bronnen voor de Kunstgeschiedenis van de Nederlanden, I, Vol. 7 (1654-1658). Brussels: Paleis der Academiën.

Filipczak, Z. Z. 1987. Picturing Art in Antwerp, 1550-1700. Princeton, New Jersey: Princeton University Press.

Franits, W. 1997. Looking at seventeenth-century Dutch art. Cambridge: Cambridge University Press. 
Henkel, A. and A. Schöne, eds. 1967. Emblemata: Handbuch zur Sinnbildkunst des XVI. und XVII.Jahrhunderts. Stuttgart: J. B. Metzlersche Verlagsbuchhandlung.

Larsen, E. 1985. Seventeenth-century Flemish painting. Freren: Luca Verlag.

Liedtke, W. A. 1984. Seventeenth- and eighteenthcentury Flemish paintings in the Metropolitan Museum of Art. 2 vols. New York: Metropolitan Museum of Art.

Moens, K. 1994. Muziek \& Grafiek. Burgermoraal en muziek in de 16de- en 17de-eeuwse Nederlanden. Exhibition catalogue. Antwerp: Hessenhuis.

Müller, W. J. 1978. Die Sprache der Bilder. Realität und Bedeutung in der niederländischen Malerei des 17. Jahrhunderts. Exhibition catalogue. Braunschweig: Herzog Anton Ulrich-Museum.

Renger, K. 1970. Lockere Gesellschaft. Zur Ikonographie des Verlorenen Sohnes und von Wirtshausszenen in der niederländischen Malerei. Berlin.

—. 1993-1994. Flemish genre painting: Low life - High life - Daily life. In The age of Rubens (Exhibition catalogue), ed. P. C. Sutton. Boston: Museum of Fine Arts; Toledo: Museum of Art.

Roodenburg, H. 1997. How to sit, stand and walk: Toward a historical anthropology of Dutch paintings and prints. In Looking at seventeenthcentury Dutch art, ed. W. Franits, 175-186. Cambridge: Cambridge University Press.

Sutton, P. C. 1993-1994. The age of Rubens. Exhibition catalogue. Boston: Museum of Fine Arts; Toledo: Museum of Art.
Vandenbroeck, P. 1984. Verbeeck's peasant weddings: A study of iconography and social function. Simiolus 14:79-124.

—. 1990. De 'salette' of pronkkamer in het 17 de-eeuwse Brabantse burgerhuis. Familieen groepsportretten als iconografische bron, omstreeks 1640-1680. Monumenten en landschappen 9(6):41-62.

Van Haute, B. 1999. David III Ryckaert. A seventeenth-century Flemish painter of peasant scenes. Turnhout: Brepols.

Van Lennep, J. 1966. Art et alchimie. Étude de l'iconographie hermétique et de ses influences. Brussels: Editions Meddens.

Vekeman, H. J. and J. Müller Hofstede. 1984. Wort und Bild in der niederländische Kunst und Literatur des 16. und 17.Jahrhunderts. Erfstadt: Lukassen.

Veldman, I. M. 1992. Images of labor and diligence in sixteenth-century Netherlandish prints: The work ethic rooted in civic morality or Protestantism? Simiolus 21(4):227-264.

Westermann, M. 2002. After iconography and iconoclasm: Current research in Netherlandish art, 1566-1700. The Art Bulletin 84(2) June:351-372.

Wieseman, M. E. 1993-1994. The art of 'Conversatie': Genre portraiture in the southern Netherlands in the seventeenth century. In The Age of Rubens (exhibition catalogue), ed. P. C. Sutton, 182-193. Boston: Museum of Fine Arts; Toledo: Museum of Art. 